\section{Public Health Education in Mexico}

The August issue of the Boletin de la Oficina Sanitaria Panamericana contains an instructive article by Dr. Angel de la Garza Brito, director of the School of Hygiene of Mexico, on the present and future of education in hygiene in his country. The old preparatory school in public health which was reorganized in April 1938 gave instruction to 130 medical men, 184 nurses and 70 health officers, as well as to an auxiliary staff consisting of statisticians, laboratory assistants and social workers for venereal diseases. In 1941 the first regular course for medical officers of health was opened. Difficulties which have been encountered are due to an almost complete lack of modern text-books and special literature on preventive medicine and public health, the scarcity of full-time teachers and the absence of basic training in preventive medicine and hygiene. These defects have been partly remedied by the preparation of synopses on each subject, and by encouraging the study of foreign languages, especially English. It has also been suggested that hospital instruction should be supplemented by a sociological approach.

\section{Urea Formaldehyde Glue for Plywood}

PLYwood is made to one of two specifications, either D.T.D.427 or B.S.S.5.V.3, requiring resistance to three hours immersion in water at $60^{\circ} \mathrm{C} .\left(140^{\circ} \mathrm{F}\right.$.) and $100^{\circ} \mathrm{C} .\left(212^{\circ} \mathrm{F}\right.$.) respectively. At present urea formaldehyde resins are used for D.T.D.427 plywood, and Tego film (paper impregnated with a phenol formaldehyde resin and used in a dry state) for the 5.V.3 plywood. Although modified urea formaldehyde glues meet the requirements of B.S.S.5.V.3, they cannot be used in the manufacture of very thin ply. wood because of the swelling caused in the thin veneers by the wet glue, and because of the penetration that takes place after pressing. The phenol formaldehyde film type of glue is, of course, immune from these troubles.

To meet this difficulty, and to reduce costs, Messrs. Aero Research, Ltd., of Duxford, Cambridge, have introduced a foamed modified urea formaldehyde glue. The amount of glue applied by any ordinary means (glue spreaders or brushes) is in excess of the optimum amount; by using the glue in the form of a foam an extremely thin uniform spread is obtained in terms of pounds of glue per square foot, although the glue layer has an appreciable thickness. Actually the volume of the glue is about doubled by a special beater machine before it is poured into the glue spreader. Under ordinary factory conditions it is possible to get a spread of $1.35 \mathrm{lb}$. of glue per 100 square feet. This foamed-up glue, known as Aerolite F.67, gives plywood meeting the requirements of specification 5.V.3. Because of the nature of the foam, it can be used with thin veneers. The press temperature required is $90^{\circ} \mathrm{C}$., so that steam-heated presses are unnecessary and the older type of press common in Great Britain, with hot-water heating, can be used; the use of pressing temperatures below $100^{\circ} \mathrm{C}$. obviates any risk of over-heating of the wood with its attendant troubles. Messrs. J. M. Steel and
Co., Ltd., of Kern House, 36-38, Kingsway, London, E.C.2, are the distributors of Aerolite glue, and all inquiries should be addressed to them.

\section{Forests of British Honduras}

THE annual report of the Forest Department of British Honduras for the year ending December 31, 1940 , is an illustration of the failure on the part of responsible administrators to understand the principles of a true forestry management. Mahogany has been exported from the country for a couple of centuries and more. The report commences with the statement that "British Honduras is essentially a producer of raw materials for export, of which in the last eighteen years an average of $79 \cdot 6$ per cent has been derived from the forests. In 1940 there was continued improvement in the export trade, and particularly so for forest produce, in spite of war conditions." There was but slight disruption of communications with North America to which a considerable proportion of these productions goes and the United Kingdom Timber Control Department purchased the whole of the lumber output. The Conservator writes: "the work of the Department in 1940 was concentrated on the most important aims of the forest policy." This policy is apparently to develop the forest estate by the maintenance of the chief export, mahogany, and chicle, etc. This is not forestry. A timber merchant ean do this; nor can it be termed a 'forest policy'. The exploitation of the forests is apparently done entirely by licensees who set up their own mills.

That the forests so worked and the amounts of valuable timber they contain is to a great extent unknown is obvious from the statement in the report that "shortage of staff has, for years, made it impossible to do much exploration in advance of exploitation"; there appears to be an idea that by giving longer terms to the licences issued, licensees will plan their work economically. In the history of forest lumbering this hope has ever remained a dead letter. The superior staff of this Department consists of a conservator and two assistant conservators. Both these latter were absent for a greater part of the year; and yet we are told that $79 \cdot 6$ per cent of the raw material exported from the Colony comes from its forests. It would have been interesting had the report told us the direction in which the sums obtained from this produce went. Do they go into the exchequer of the Colony and are they spent in the improvement of the conditions of the people? If the answer is in the affirmative, how long will the forests stand the drain upon them in the absence of the introduction of a true conservative management which could solely be enacted and maintained by an adequate forest staff? According to the report, the latter can only be considered to be present in name.

\section{British Association Seismological Committee}

THE report of the British Association Seismological Committee for 1941 has just been received. It shows that some progress is being made in spite of 
war conditions. The new-type electrically driven recording drums for the Milne-Shaw seismographs are proving satisfactory in India. The rotation of the drum is particularly uniform and there is no 'backlash'. This result has been achieved by pivoting the electric motor eccentrically on a spindle, and permitting it to fall by gravity into mesh with the gear attached to the drum. It may be described as a 'floating' contact in place of the usual fixed centres. Difficulties in connexion with the International Seismological Summary are being successfully overcome at Oxford. Jeffreys has investigated the deep earthquake of June 29, 1934, and has obtained from it helpful readings of the receding $(D E)$ branch of $P K P$. The table of $P K P$ has thus been improved and a table also constructed for $s P$. Stoneley makes some very helpful and pertinent remarks concerming the integration of seismograms in connexion with the long-wave phase of earthquakes. There need now be no hesitation in accepting the usual identification of the early part of the long-wave phase (apparent velocities $4 \cdot 4-4 \cdot 0 \mathrm{~km}$./sec.) as Love waves.

\section{Compounding in Locomotive Design}

Mr. W. A. Stanier delivered the presidential address to the Institution of Mechanical Engineers on October 24, when he discussed "The Position of the Locomotive in Mechanical Engineering". Although a standard feature of marine reciprocating design, compounding has not found extensive favour in Europe except in France. In England it has been the subject of repeated trials-no less than 12 per cent of the papers ever read before the Institution are on compounding-and in theory it has obvious advantages over simple expansion. These advantages are specially marked at working pressures higher than $300 \mathrm{lb}$. per sq. in. Attempts in Great Britain have contained defects, condensation causing serious loss, and lack of understanding of the principles of steam flow have often rendered the engines more sluggish than their simple expansion contemporaries. Superheating, which brought fresh life to the compound engine on the Continent, has only been applied to any scale to one British type, the 'Midland' compound; within the limits of its size, good work has been done and is still being done by this class. It has, however, never been modernized as regards its cylinder and valve-gear design, so its actual efficiency is below that of the present-day simple expansion engine. It is also possible to understand now why the French De Glehn compounds, imported by the Great Western Railway in 1903 and 1905, did not give results superior to the simple-expansion designs of Churchward. It is impracticable to combine within the British loading gauge, however, both the large lowpressure cylinders required, and the bearing and crank dimensions required by compound locomotives.

\section{Northern Ecological Association}

THE Northern Ecological Association was founded by the late Mr. R. J. Flintoft, of Goathland, Yorks, who organized workers in various fields of natural science in their own localities in the north of England. Valuable work had been done in this way, and it was felt that the organization should not be allowed to lapse, but should be placed on a permanent basis. Accordingly a special meeting of the Association was held at York on November 23, and it was decided. to re-enact the existing constitution and to adopt the existing name. The officers of the Association are as follows : president, Dr. W. Collinge ; secretary and treasurer, Mr. J. L. Forrest, Eversfield, Goathland, Yorks ; editor, M. Dallman.

\section{Dr. E. N. Miles Thomas}

Dr. E. M. Des.r, Department of Botany, Westfield College, London (at St. Peter's Hall, Oxford) writes : "Dr. E. N. Miles Thomas, who is widely known amongst botanists for her contributions to the study of seedling anatomy, retired from her position as head of the Department of Biology at University College, Leicester, in 1937. Thereafter she occupied a research room at Westfield College (University of London), and for a time continued her many professional activities. Her health, however, was already seriously impaired. The evacuation of the College to Oxford and other difficulties in connexion with the War situation probably added greatly to the overstrain from which she was suffering. Early in 1940 she was found to have lost almost completely her power of memory, a condition which is now unfortunately regarded as permanent, although her general health has somewhat improved. Her research effects are housed at the Jodrell Laboratory, Kөw."

\section{Recent Earthquakes}

IN addition to being recorded on all the seismograms at Kew Observatory, the earthquake of November 25 was recorded on the electrometer record of the rain electrograph. This earthquake, which affected Lisbon, gave very large amplitudes at Kow. The real ground amplitude caused by $P(18 \mathrm{~h} .08 \mathrm{~m} .22 \mathrm{~s}$. U.T.) exceeded $300 \mu$, the amplitude caused by $S$ (18h. 13m. 45s. U.T.) exceeded $800 \mu$ and the maximum may have exceeded $2 \mathrm{~mm}$. A tentative interpretation of the records shows a compression from the southwest (azimuth $233^{\circ}$ ) and an epicentral distance near $3,600 \mathrm{~km}$. The epicentre may thus have been near $28^{\circ} \mathrm{N}$., $29^{\circ} \mathrm{W}$., in the Atlantic Ocean south of the Azores. On December 4 an earthquake of considerable severity was felt at Rangoon though no damage is reported. On December 6 earthquakes were reported from Santiago and from San José in Costa Rica. Considerable damage was reported though full details are not yet available.

The United States Coast and Geodetic Survey, in co-operation with Science Service and the Jesuit Seismological Association, has found the epicentres of the earthquakes of October 3 and October 5. The earthquake of October 3 at $16 \mathrm{~h} .13 \cdot 2 \mathrm{~m}$. U.T. had its epicentre near lat. $40 \cdot 6^{\circ} \mathrm{N}$., long. $124 \cdot 6^{\circ} \mathrm{W}$., which is in northern California in the neighbourhood of Cape Mendocino. On the basis of instrumental reports from seven seismograph stations, the epicentre of the earthquake of October 5 at $10 \mathrm{~h} .11 \cdot 2 \mathrm{~m}$. has been calculated to be lat. $15^{\circ} \mathrm{S}$., long. $173^{\circ} \mathrm{W}$., which is in the Pacific Ocean between the Islands of Samoa and the Fiji Islands. All interpretations and calculations are tentative. 